\title{
A Neoproterozoic Petroleum System in The Dalradian Supergroup, Scottish Caledonides
}

\section{TIMOTHY BATA ${ }^{1} \&$ JOHN PARNELL ${ }^{1}$}

\author{
${ }^{1}$ Department of Geology and Petroleum Geology, University of Aberdeen, Aberdeen AB24 \\ 3UE, U.K. \\ (e-mail:timothybata@abdn.ac.uk)
}

\begin{abstract}
(Abstract) Petroleum systems occur in the Neoproterozoic in several parts of the world, based on organic-rich hydrocarbon source rocks deposited during late Neoproterozoic high sea level. The Dalradian Supergroup in Argyll, Scotland, shows evidence for coupled source rock and reservoir rock. The Easdale Slate and laterally up-dip Scarba Conglomerate in the Easdale Subgroup, Argyll Group, were deposited as deep water mudrocks and submarine fan coarse pebbly sandstone respectively. The Easdale Slate contains several percent organic carbon, rich enough to be a good source rock. The pore-space in the sandstones of the Scarba Conglomerate is infilled with carbonaceous matter that originated as an oil residue. Pyrite spatially associated with the oil residue may reflect microbial sulphate reduction, as occurs in many younger petroleum reservoirs. Despite greenschist facies metamorphism, the Easdale Subgroup records a hitherto unrecognized petroleum system, which adds to a global picture of late Neoproterozoic hydrocarbon generation.
\end{abstract}


Although most hydrocarbon resources lie within Phanerozoic rocks, it is recognized that there are hydrocarbon prospects in the Proterozoic, especially the Neoproterozoic (1000-542 Ma) in several parts of the world, including North and South America, Africa, Australia, Asia and the Middle East (Benshati et al. 2009; Bhat et al. 2009; Aziz and Ghnia 2009; Craig et al. 2009). Where Neoproterozoic rocks have been preserved from deformation and metamorphism, there is no reason why they should not be prospective. The best quality source rocks contain organic matter of microbial origin, and Precambrian organic matter is predominantly microbial, so source rocks are to be expected in Proterozoic marine successions and have been widely identified (Craig et al. 2009, 2013). The extensive development of anoxic conditions in the Neoproterozoic makes this time especially favourable to source rock deposition (Johnson et al. 2010).

In western Europe, the deformation and metamorphism associated with repeated orogenies has left the Precambrian unprospective. However, fossil petroleum systems should be evident in exhumed Precambrian metasediments. The Dalradian Supergroup is part of the record of Neoproterozoic Earth history in the Caledonian orogenic belt, recording deposition on the margin of eastern Laurentia during the breakup of the Pannotia Supercontinent and development of the Iapetus Ocean (Anderton 1982, 1985). It consists of a succession of marine shales, limestones and sandstones representing fluctuating sea level, and extends from the Shetland Islands through mainland Scotland and across the northern part of Ireland. The Dalradian Supergroup represents one of the most complete Neoproterozoic-Cambrian successions (Brasier \& Shields 2000). Isotopic signatures typical of global values for carbonates and sulphates suggest that they were deposited in an open marine environment (Prave et al. 2009; Moles et al. 2013). In a similar Phanerozoic succession, we would expect to find combinations of source and reservoir rock that constitute a petroleum system, but they 
have not hitherto been identified in the Dalradian. We show here that a petroleum system existed where it would be expected in a favourable stratigraphic setting.

The Dalradian rocks lie at a high structural level where the metamorphic grade is low, and consequently some of their original sedimentary features are still preserved. Dalradian sandstones are mineralogically mature, i.e. quartz-rich (Arnaud 2004), so were potentially good reservoirs. Many Dalradian shales are carbonaceous, but an exceptionally carbonaceous unit, the Easdale Slate and equivalents, of the Easdale Subgroup, Argyll Group (Figs. 1), can be traced for over $450 \mathrm{~km}$ across Scotland and Ireland. This unit contains up to 6.3 wt.\% total organic carbon, and would have been richer before oil generation and metamorphism, so constituted a good source rock (Peters 1986). The Easdale Slate was deposited between two diamictites attributed to the Sturtian and Marinoan glaciations (715 to $635 \mathrm{Ma}$ ) (Prave et al. 2009); a period from which organic-rich shales are preserved in several parts of the world, including South America, Africa and Antarctica (Craig et al. 2009, 2013; Le Heron \& Craig 2012). The deep water Easdale Slate passes laterally up-dip to, a coarse pebbly quartzose sandstone, the Scarba Conglomerate (Figs. 1, 2) The Scarba Conglomerate averages $450 \mathrm{~m}$ thick, and is attributed to a submarine fan environment, including mass-flow and turbidite deposits on a north-dipping palaeoslope (Anderton 1985, Tanner et al. 2013). It fines northwards and upwards, and is gradational into the Easdale Slate. Both are overlain by another pelitic unit, the Craignish Phyllite (equivalent to Ardrishaig Phyllite, Port Ellen Phyllite). Pseudomorphs after gypsum show that the Craignish Phyllite was partially evaporitic (Tanner et al. 2013), a feature regarded as favourable to sealing capacity. This is the geometry of a classical stratigraphic trap (Magoon \& Dow 1994). The validity of the trap can be evaluated by proving an oil residue in the Scarba Conglomerate. 
Methods of Study. Black sandstones from the Scarba Conglomerate and the transition zone between the conglomerate and the Easdale Slate were sampled at Lagg (National Grid Reference NR 588774), Inverlussa (NR 643865) and Black Mill Bay (NM 732087) on the islands of Jura and Luing (Fig. 2; localities described by Anderton 1977; Baldwin and Johnson 1977; Tanner et al. 2013).Selected samples were then prepared as polished thin sections and examined using an ISI ABT-55 scanning electron microscope with Link Analytical 10/55S EDAX facility. The carbon content of some of the samples was measured using a LECO CS225 elemental analyzer. Based on the results of petrographic study, some samples were prepared for determination of the total organic carbon (TOC) content.

An oil-charged reservoir. The Scarba Conglomerate is very dark in colour throughout its outcrop. It consists of black sandstone and conglomerate along the eastern seaboard of Jura, and black sandstones occur in the transition zone with the Easdale Slate on the west side of Luing (Fig. 1). This contrasts strongly with the underlying Jura Quartzite, which is distinctly white, as are most other Dalradian sandstones. Both the Scarba Conglomerate and Jura Quartzite are quartzose sands, so the difference in colour does not reflect primary mineralogy. The Scarba Conglomerate is distinctive in having an elevated total organic carbon (TOC) content. The mean value is 0.22 wt. $\%(n=10)$, with a maximum of 0.33 wt.\%. In contrast, the mean value for the Jura Quartzite is only $0.07 \mathrm{wt} \%(\mathrm{n}=10)$. The elevated organic carbon content of the Scarba Conglomerate could be due to a carbonaceous residue or carbonaceous clasts. A typical Phanerozoic black sandstone with oil residue in the pore space, from the Devonian of Caithness, has a mean organic carbon content of 0.33 wt. \% $(n=10)$ (Fig. 3B), suggesting that this may also be the origin of the carbon in the Dalradian sandstone.The Scarba Conglomerate TOC content would have been higher before loss of volatile organic compounds during metamorphism. Petrographic evidence confirms that the 
carbonaceous matter occurs only in the pore space (Figs. 4B \& 4D). Furthermore, it is not admixed with inorganic mineral matter (e.g. silicates) (Fig. 4D), so does not represent clasts of carbonaceous shale. It is therefore considered to be a residue of oil.

In addition to a suitable geometry, the Scarba Conglomerate was especially favoured as a reservoir because of its abundance of mineralogically mature (i.e. quartz-rich) sand. This was available from the underlying Jura Quartzite, a shelf deposit in which shallow marine reworking had created an extensive quartz sand stretching from Argyll to Ireland. The headwaters of the Scarba Conglomerate turbidite system would have cut downwards into this almost limitless supply of mature sand, and fed the turbidite with sand relatively free of argillacous matrix.

The occurrence of an oil residue in the Scarba Conglomerate but not the Jura Quartzite implies development of a direct up-dip migration pathway from the Easdale Slate into the Scarba Conglomerate at the time of oil charging. The oil residue in pores of the Scarba Conglomerate occupies an estimated volume of $11 \%$. This implies that the Scarba Conglomerate was uncemented and had an estimated average porosity of $11 \%$ as at the time of oil charging. At present, the Scarba Conglomerate has a very low porosity $(<1 \%)$. This is because its pores are filled with oil residue (Fig. 4B). The oil residue forms irregular shapes in the pore-spaces. This is characteristic of inspissated (degraded) solid hydrocarbon, unlike viscous hydrocarbons which adhere to the pore walls (e.g. Parnell 1987). Emplacement of oil into the pores of the Scarba Conglomerate must have halted aqueous diagenetic processes as post-petroleum cement has not been observed within its pores. Aqueous diagenetic processes were not disrupted in the Jura Quartzite since oil did not migrate into its pores. It now exhibits extensive cementation by quartz. Some quartz overgrowths in it are large (Fig. 4C), which implies that it was porous when cementation commenced. 
A normal geothermal gradient of about $25{ }^{\circ} \mathrm{C} / \mathrm{km}$ would have brought the deepest portion of the Easdale Slate source rock into the oil window (a temperature above $70{ }^{\circ} \mathrm{C}$ ) during deposition of the Craignish Phyllite. The gradient would have steepened during the magmatic activity which produced the Tayvallich Volcanic Formation at about $600 \mathrm{Ma}$ (Dempster et al. 2002), and realised much of the remaining hydrocarbon potential.

Crystal clusters of pyrite, up to 200 microns size, occur spatially associated with the oil residue in the pore space of the Scarba Conglomerate (Fig. 4D). The occurrence of pyrite is comparable with others found in fossil oil reservoirs (e.g. Fallick et al. 2012), assumed to reflect microbial consumption of oil. Oil reservoirs can be attacked by specialized chemoorganotropic sulphate-reducing bacteria (Mason \& Kirchner 1992), which degrade the oil and leave pyrite as a bi-product. The mudrocks (now slate, phyllite) in the succession are also pyritic, and yield sulphur isotope data interpreted to reflect microbial sulphate reduction (Lowry et al. 2005; Moles et al. 2013), so microbial activity in the sandstones is likely. The pyrite in the pore space of the Scarba Conglomerate is consistent with our interpretation of the carbonaceous matter as a residue of oil.

The Scarba Conglomerate has a mean thickness about $450 \mathrm{~m}$ over an outcrop length of $50 \mathrm{~km}$ (Fig. 2). The outcrop is approximately parallel with the palaeoslope and sediment transport direction (Anderton 1977).Adopting conservative values of $10 \mathrm{~km}$ width, thinning in linear manner to the margins from the measured $450 \mathrm{~m}$ thickness, and thereby assuming that this was the maximum thickness (unlikely), a net-to-gross ratio (proportion of rock volume consisting of sand and functioning as reservoir) of 0.5 and a mean porosity of $10 \%$, the volume of rock represents a potential volume of $3.5 \times 10^{4}$ million barrels of oil, using an equivalence of $6.29 \mathrm{bbl}$ oil for $1 \mathrm{~m}^{3}$ oil. Turbidite reservoirs and analogues of similar magnitude, such as the Paleocene-Eocene of the central North Sea and Cenozoic foreland basins of continental Europe, have greater width-length ratios, net-to-gross ratios and mean 
porosities (Pettingill 1998; Hempton et al. 2005; Covault \& Graham 2008), suggesting that the calculated oil volume may be significantly underestimated. Nevertheless, adopting a conservative recovery factor (fraction of oil in place that can be extracted) of $10 \%$, this volume is comparable with those of giant turbidite fields producing today (Pettingill 1998).

Conclusion. The Argyll Group of the Neoproterozoic Dalradian Supergroup in Scotland includes a fossil petroleum system. The disposition of organic-rich shale, quartzose sandstone and sealing shale in the Easdale Subgroup suggests a potential stratigraphic trap for a petroleum play. The sandstone, the Scarba Conglomerate, is black, with elevated organic carbon content concentrated in pore spaces, indicating a former oil residue. The Easdale Slate and its equivalents are organic-rich for $450 \mathrm{~km}$ strike length across Scotland and Ireland, limited only by the termination of outcrop, so there are likely to be other fossil oil reservoirs awaiting discovery. Evidence for a petroleum system on the Laurentian margin adds to growing evidence for global hydrocarbon generation during the late Neoproterozoic.

The deposition of Neoproterozoic marine successions along the margins of Laurentia and Baltica prior to the development of the Iapetus Ocean can be compared to the evolution and deposition of the petroleum-bearing sedimentary successions along the current Atlantic margin. Therefore evidence for more Neoproterozoic petroleum systems should be expected along the margins of Laurentia and Baltica where the metamorphic grade is not high. 


\section{References}

ANDERTON, R. 1977. The Dalradian rocks of Jura. Scottish Journal of Geology, 13(2), 135142.

ANDERTON, R. 1979. Slopes, submarine fans, and syn-depositional faults: sedimentology of parts of the Middle and Upper Dalradian in the SW Highlands of Scotland. In: HARRIS, A.L., HOLLAND, C.H. \& LEAKE, B.E. (eds), The Caledonides of the British Isles- reviewed. Geological Society London, Special Publication 8, 483-488.

ANDERTON, R. 1982. Dalradian deposition and the late Precambrian-Cambrian history of the N Atlantic region: a review of the early evolution of the Iapetus Ocean. Journal of the Geological Society, 139, 421-431.

ANDERTON,R. 1985. Sedimentation and tectonics in the Scottish Dalradian. Scottish Journal of Geology, 21, 407-436.

ARNAUD, E. (2004) Giant cross-beds in the Neoproterozoic Port Askaig Formation, Scotland: implications for snowball Earth. Sedimentary Geology,165, 155-174.

AZIZ, A. \& GHNIA, S. 2009. Distribution of infracambrian rocks andthe hydrocarbon potential withinthe Murzuq and Al Kufrah Basins, NW Africa. In:CRAIG, J., THUROW, J., THUSU, B., WHITHAM, A. \& ABUTARRUMA, Y. (Eds) Global Neoproterozoic petroleum systems: The emerging potential in North Africa. Geological Society, London, Special Publication, 326, 211-219.

BALDWIN, C. T. \& JOHNSON, H. D. 1977. The Dalradian rocks of Lunga, Luing and Shuna.Scottish Journal of Geology, 13, 143 - 154. 
BENSHATI, H., KHOJA, A. \& SOLA, M. 2009. Infracambrian sediments in Libyan sedimentary basins In: CRAIG, J., THUROW, J., THUSU, B., WHITHAM, A. \& ABUTARRUMA, Y. (Eds) Global Neoproterozoic petroleum systems: The emerging potential in North Africa. Geological Society, London, Special Publication, 326, 181191.

BHAT, G. M., RAM, G. \& KOUL, S. 2009. Potential for oil and gas inthe Proterozoic carbonates (Sirban Limestone) of Jammu, Northern India. In: CRAIG, J., THUROW, J., THUSU, B., WHITHAM, A. \& ABUTARRUMA, Y. (Eds) Global Neoproterozoic Petroleum Systems: The Emerging Potentialin North Africa.Geological Society,London, Special Publication,326, 245-254.

BRASIER, M. D. \& SHIELDS, G. 2000. Neoproterozoic chemostratigraphy and correlation of the Port Askaig glaciation, Dalradian Supergroup of Scotland. Journal of the Geological Society, London,157, 909 - 914.

COVAULT, J. A. \& GRAHAM, S. 2008. Turbidite architecture in proximal foreland basinsystem deep-water depocenters: Insights from the Cenozoic of Western Europe. Australian Journal of Earth Sciences, 101, 36-51.

CRAIG, J., THUROW, J., THUSU, B., WHITEMAN, A. \& ABUTARRUMA, Y. 2009. Global Neoproterozoic petroleum systems: the emerging potential in North Africa: Geological Society, London, Special Publication,326, 1-25.

CRAIG, J., BIFFI, U., GALIMBERTI, R.F., GORTER, J.D., GHORI, K.A.R., HAKHOO, N., LE HERON, D.P., THUROW, J. \& VECOLI, M. 2013. The palaeobiology and geochemistry of Precambrian hydrocarbon source rocks. Marine and Petroleum Geology 40, 1-47. 
DEMPSTER, T. J., ROGERS, G., TANNER, P. W. G., BLUCK, B. J., MUIR, R. J., REDWOOD, S. D., IRELAND, T. R. \& PATERSON, B. A. 2002. Timing and deposition, orogenesis and glaciation within the Dalradian rocks of Scotland. Journal of the Geological Society, London, 156, 83-94.

FALLICK, A.E., BOYCE, A.J. \& MCCONVILLE, P. 2012. Sulfur stable isotope systematics in diagenetic pyrite from North Sea hydrocarbon reservoirs revealed by laser combustion analysis. Isotopes in Environmental and Health Studies, 48, 144165.

HEMPTON, M., MARSHALL, J., SADLER, S., HOGG, N., CHARLES, R. \& HARVEY, C. 2005. Turbidite reservoirs of the Sele Formation, Central North Sea: geological challenges for improving production. In: DORE, A. G. \& VINING, B.A. (eds) Petroleum Geology: North-West Europe and Global Perspectives - Proceedings of the 6th Petroleum Geology Conference, 449-459.

JOHNSON, D.T., POULTON, S.W., DEHLER, C., PORTER, S., HUSSON, J,, CANFIELD, D. E. \& KNOLL, A. H. 2010. An emerging picture of Neoproterozoic Ocean chemistry: insight from the Chuar Group Grand Canyon, USA. Earth and Planetary Science Letters, 290, 64-73

LE HERON, D.P.\& CRAIG,J. 2012. Neoproterozoic deglacial sediments and their hydrocarbon source rock potential. Geological Society, London, Special Publication, 368, 381-393.

LOWRY, D., BOYCE, A. J., FALLICK, A.E., STEPHENS, W.E., \& GRASSINEAU, N.V., 2005, Terrane and basement discrimination in northern Britain using sulphur isotopes and mineralogy of ore deposits. In: MCDONALD, I., BOYCE, A.J., BUTLER, I.B., HERRINGTON, R.J., \& POLYA, D.A. (editors), Mineral Deposits and Earth Evolution. Geological Society, London,Special Publications 248, 133-151. 
MAGOON, L. B., \& W. G. DOW, 1994, The petroleum system, in: MAGOON, L. B., \& DOW, W. G. (eds) The petroleum system from source to trap: American Association of Petroleum Geologists, Memoir 60, 3-24.

MASON, G. M., \& KIRCHNER, G. 1992.Authigenic pyrite: evidence for a microbial origin of tar sand. Fuel, 71(12),1403-1405.

MOLES, N.R., BOYCE, A. J. \& FALLICK, A. E. 2013. Abundant sulphate in the Neoproterozoic ocean: implications of constant $\delta^{34} \mathrm{~S}$ of barite in the Aberfeldy SEDEX deposits, Scottish Dalradian. Geological Society, London, Special Publication in press.

PARNELL, J. 1987. Secondary porosity in hydrocarbon-bearing transgressive sandstones on an unstable Lower Palaeozoic continental shelf, Welsh Borderland. Geological Society, London, Special Publications, 36(1), 297-312

PETERS, K. E. 1986. Guidelines for evaluating petroleum source rock using programmed pyrolysis. American Association of Petroleum Geologists Bulletin, 70 (3), 318-329.

PETTINGILL, H.S. 1998. Lessons learned from 43 turbidite giant fields. Oil and Gas Journal, October 12 1998, 93-96.

PRAVE, A. R., FALLICK, A. E., THOMAS, C. W. \& GRAHAM, C. M. 2009. A composite C-isotope profile for the Neoproterozoic Dalradian Supergroup of Scotland and Ireland. Journal of the Geological Society, London,166, 845-857.

TANNER,P.W. G., BENDALL, C.A., PICKETT, E. A., ROBERTS, J. L., TREAGUS, J. E. \&STEPHENSON, D. 2013. The Dalradian rocks of the south-west Grampian Highlands of Scotland. Proceedings of the Geologists Association, 124, 83-147. 


\section{Figure captions}

Fig. 1. Summary stratigraphy for upper part of the Dalradian Supergroup, including Easdale Subgroup of the Argyll Group with interpreted depositional environments and showing petroleum system (modified from Anderton 1985; Tanner et al. 2013). Horizon of Marinoan glaciation as proposed by Prave et al. (2009).

Fig. 2. Map of SW Scotland, showing outcrop of Scarba Conglomerate and three sampling localities (BMB, Black Mill Bay), and schematic cross-section across region of map. It should be noted that Easdale Slate passes laterally and up-dip into Scarba Conglomerate. Adapted from Anderton (1979).

Fig. 3 Total organic carbon (TOC) data. (a) Cross-plot of sulphur against TOC for Easdale Slate. (b) Histogram showing comparison of TOC values between Scarba Conglomerate, Jura Quartzite and Devonian bituminous sandstones.

Fig. 4 Photomicrographs of (a) hand specimens of Scarba Conglomerate (black) and Jura Quartzite (white); (b) thin section of sandstone, Black Mill Bay, showing lack of grain overgrowths, and black (oil residue) globules (arrowed) and grain coatings; (c) thin section of Jura Quartzite, Sound of Jura, showing conspicuous quartz overgrowths (arrowed) on detrital grains, and lack of pore space; (d) Backscattered electron micrograph of Scarba Conglomerate from Black Mill Bay, showing black oil residue in pore space. Inclusions of pyrite (arrowed) associated with the oil residues. 


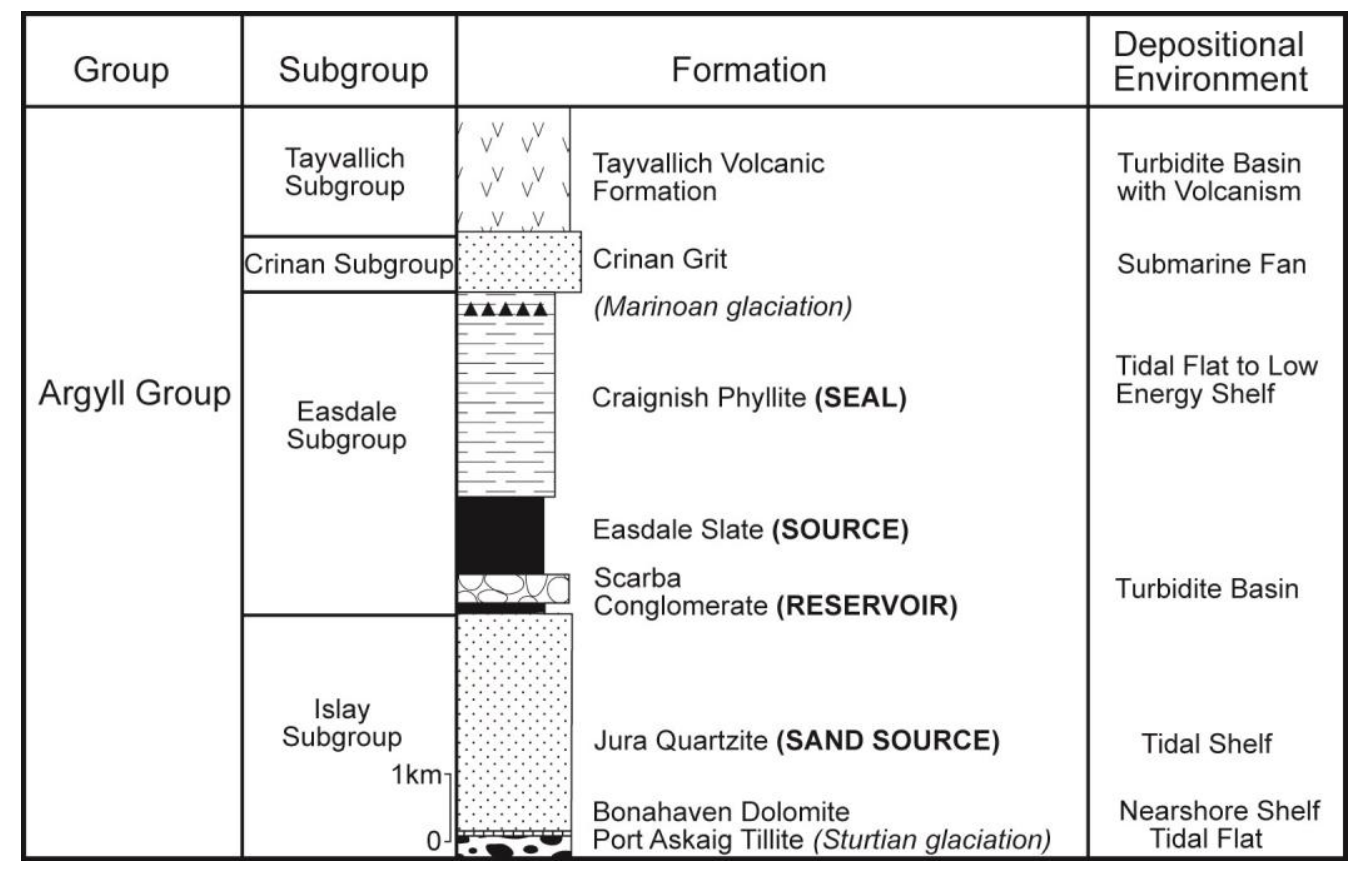

Figure 1

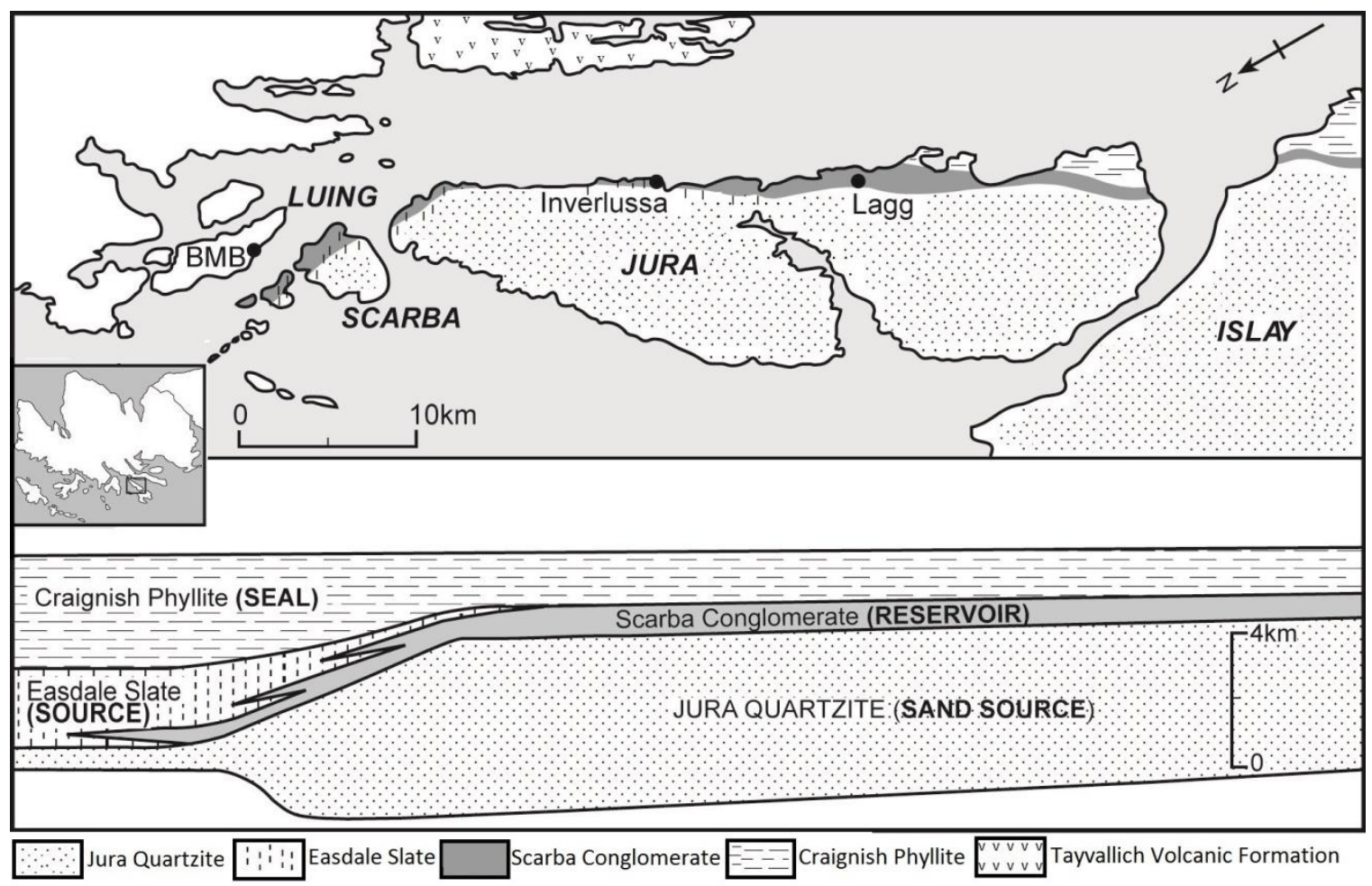

Figure 2 

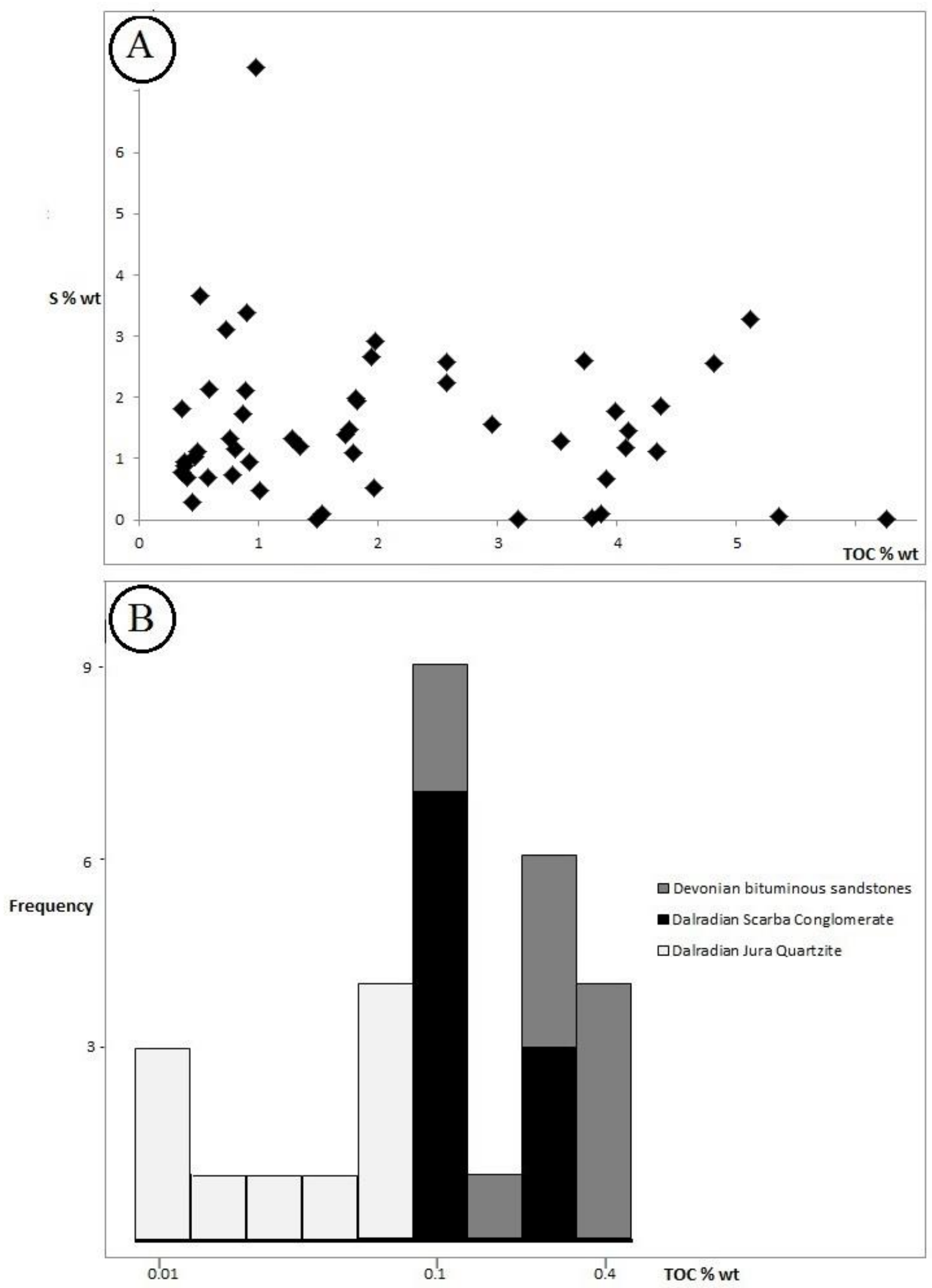

Figure 3 

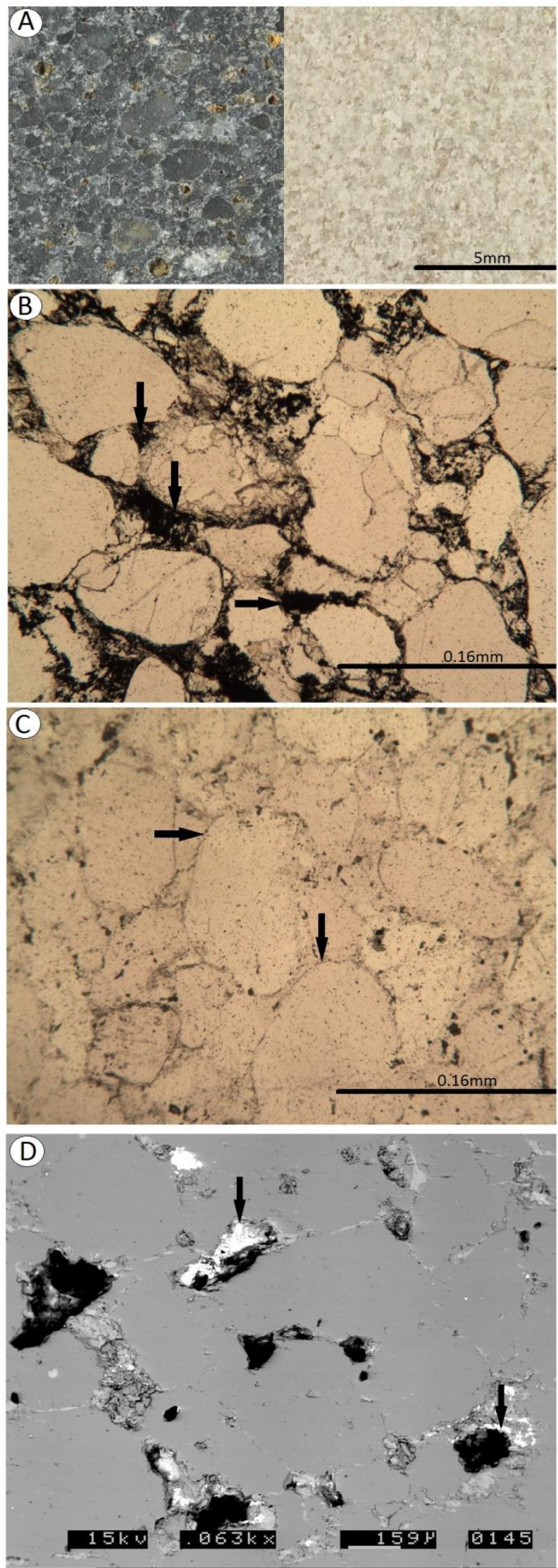

Figure 4 